\title{
Vocal activity and acoustic structure of the rutting calls of Siberian wapiti (Cervus elaphus sibiricus) and their imitation with a hunting luring instrument
}

\begin{abstract}
Ilya A. Volodin*, Elena V. Volodina, Roland Frey \& Inna L. Maymanakova
ABSTRACT. This study on Siberian wapiti (Cervus elaphus sibiricus) provides data on rutting vocal activity (bugles per hour), collected using four synchronized automated recording systems in natural habitats in the Western Sayan Mountains (Russia). Also, this study provides first comparison of naturally produced male bugles with their imitation using a traditional hunting technique of blowing into a hollow pipe with a mouthpiece. Stag vocal activity weakly negatively correlated to air temperature and ceased completely during three very cold days with snowfall. Stag bugles $(n=153)$ were high-pitched, with an average maximum fundamental frequency $(f 0)$ of $1.23 \pm 0.21 \mathrm{kHz}$, a minimum $f 0$ of $0.29 \pm 0.05 \mathrm{kHz}$ and a duration of $3.07 \pm 0.52 \mathrm{~s}$. Hind alarm barks $(n=12)$ were significantly lower in maximum $f 0=0.93 \pm 0.08$ $\mathrm{kHz}$, significantly higher in minimum $f 0=0.34 \pm 0.06 \mathrm{kHz}$ and much shorter $(0.20 \pm 0.03 \mathrm{~s})$ compared to male bugles. Male bugles were similar in the acoustic structure with their imitations, produced by a human using a luring wind instrument $(n=27)$, what provides a support to the hypothesis of forced airflow through a narrow, highly tensed larynx and vocal tract as a production mechanism of the extremely high-pitched bugles of wapiti.
\end{abstract}

KEY WORDS: mammals, Cervidae, vocal behaviour, rutting bugles, alarm calls.

Ilya A. Volodin [volodinsvoc@gmail.com], Department of Vertebrate Zoology, Faculty of Biology, Lomonosov Moscow State University, Vorobievy Gory 1/12, Moscow 119991, Russia; Elena V.Volodina [volodinsvoc@mail.ru], Scientific Research Department, Moscow Zoo, Bolshaya Gruzinskaya str. 1, Moscow 123242, Russia; Roland Frey [Frey@IZW-berlin.de], Leibniz Institute for Zoo and Wildlife Research, Alfred-Kowalke-Str. 17, 10315 Berlin, Germany; Inna L. Maymanakova [inna_maymanakova@mail.ru], The Nature State Reserve “Khakassian”, Tsukanov str. 164, Abakan 655017, Republic of Khakassia, Russia.

\section{Вокальная активность и акустическая структура гонных криков сибирского марала (Cervus elaphus sibiricus) и их имитация с помощью охотничьего манного инструмента}

\author{
И.А. Володин*, Е.В. Володина, Р. Фрай, И.Л. Майманакова
}

РЕЗЮМЕ. Это исследование сибирского марала (Cervus elaphus sibiricus), в котором приведены данные по гонной вокальной активности (криков в час), собранных с использованием четырех синхронизированных автоматических записывающих систем в естественных местообитаниях марала в Западных Саянах (Россия). Кроме того, в этом исследовании впервые приводится сравнение естественных звуков маралов с их имитацией с помощью традиционной охотничьей методики продувания воздуха в полую трубку с мундштуком. Вокальная активность самцов марала слабо отрицательно коррелировала с температурой воздуха и полностью прекратилась в течение трех очень холодных дней со снегопадом. Звуки самцов $(n=153)$ были высокочастотными, со средней максимальной основной частотой $(f 0) 1.23 \pm 0.21$ кГц, минимальной $f 00.29 \pm 0.05$ кГц и длительностью $3.07 \pm 0.52$ с. Тревожные лаи самки $(n=12)$ были достоверно ниже по максимальной $f 0=$ $0.93 \pm 0.08$ кГц, достоверно выше по минимальной $f 0=0.34 \pm 0.06$ кГц и намного короче $(0.20 \pm 0.03 \mathrm{c})$ по сравнению с гонными звуками самцов. Имитированные $(n=27)$ и естественные гонные звуки самцов были очень сходными по акустической структуре, что косвенно подтверждает гипотезу усиленного продувания воздуха через узкое отверстие в гортани как механизма звукопродукции у маралов и вапити.

КЛЮЧЕВЫЕ СЛОВА: млекопитающие, Cervidae, вокальное поведение, гонные крики, крики тревоги. 


\section{Introduction}

The species Cervus elaphus L., 1758 is widely distributed all over the Holarctic region. Within this geographical area, C. elaphus diverged into a number of subspecies or closely related species differing substantially by their body size (Heptner et al., 1961; Fedosenko, 1980; Geist, 1998; Danilkin, 1999), morphology (Shtarev, 1970; Geist, 1998; Frey et al., 2012; Frey \& Riede, 2013), and also by the acoustic structure of stag rutting calls (Nikol'skii et al., 1979, 1987; Nikol'skii, 1984; Geist, 1998; Frey \& Riede, 2013; Volodin et al., 2013). Phylogenetic studies suggest a close relationship between Siberian and American wapiti (Cervus elaphus sibiricus Severtzov, 1872 and C. e. canadensis Erxleben, 1777 or C. canadensis), which divergence was caused by geographical isolation by Bering Sea occurred only 9000 years ago (Mahmut et al., 2002; Ludt et al., 2004; Kuznetsova et al., 2012). As a consequence, vocalizations of Siberian wapiti are much more similar to those of American wapiti than to European red deer (Tembrock, 1965; Nikolski \& Wallschlager, 1983; Volodin et al., 2013). European red deer stags produce low-pitched roars with fundamental frequency $(f 0)$ ranges from 40 to $380 \mathrm{~Hz}$ : Corsican C. e. corsicanus Erxleben, 1777 (mean $f 0=40 \mathrm{~Hz}$ : Kidjo et al., 2008); Scottish C. e. scoticus Lonnbert, 1906 (mean $f 0=107-174 \mathrm{~Hz}$ : Long et al., 1998; Reby \& McComb, 2003); Iberian C. e. hispanicus Hilzheimer, 1909 (mean $f 0=180-186$ Hz: Frey et al., 2012; Passilongo et al., 2013); C. e. hippelaphus Erxleben, 1777 (maximum $f 0=273 \mathrm{~Hz}$ : Bocci et al., 2013). In contrast, the available data for American and Siberian wapiti suggest produce high-pitched bugles with an $f 0$ above $1000 \mathrm{~Hz}$ : Siberian wapiti from Altai C. e. sibiricus (Nikol'skii, 2011); Canadian wapiti C. e. canadensis (Struhsaker, 1968); Roosevelt wapiti C. e. roosevelti Merrian, 1897 (Bowyer \& Kitchen, 1987), Tule wapiti C. e. nannodes Merriam, 1905 (Volodin et al., 2013) and Rocky Mountain wapiti $C$. e. nelsoni Bailey, 1935 (Feighny et al., 2006; Frey \& Riede, 2013). Bactrian stags C. e. bactrianus Lydekker, 1900, living today in the area of origin of C. elaphus in Central Asia (Heptner et al., 1961; Mahmut et al., 2002; Ludt et al., 2004), produce both a low and a high $f 0$, either singly or simultaneously (Nikol'skii, 1975; Volodin et al., 2013). At expansion in opposite directions from the centre of origin, the European red deer lost the high $f 0$, whereas the Siberian and American wapiti lost the low $f 0$ (Frey \& Riede, 2013; Volodin et al., 2013).

The reasons and triggering factors of this vocal divergence are unclear to date, although its anatomical basis was investigated in detail (Titze \& Riede, 2010; Frey \& Riede, 2013). The puzzle of vocal diversity of wapiti is especially incomplete, and acoustic variation has been considered in some detail only for Canadian wapiti (Feighny et al., 2006). In this context, the study of Siberian wapiti is promising, as their rutting vocalization can be expected to be intermediate in acoustic structure between Bactrian and American subspecies and, at the same time, to differ strongly from those of European subspecies. Published evidence on the acoustic structure of Siberian wapiti is scarce and limited to few spectrograms of rutting bugles (Nikol'skii et al., 1979; Nikolski \& Wallschlager, 1983; Nikol'skii, 1984, 2011; Volodin et al., 2013). Factors affecting the dynamics of vocal activity in Siberian wapiti during the rut were not quantitatively estimated so far.

Another focus of this work was the imitation of stag rutting bugles by human hunters using traditional, selfmade devices with a pipe-like luring instrument with mouthpiece. An experienced hunter can reliably imitate the rutting bugles of Siberian wapiti to effectively attract stags and hinds to approach the hunter at close distance. Therefore, the luring instrument provides a model of stag vocal production. The mechanisms of sound production of very high-frequency bugles by wapiti with their long vocal folds are poorly understood so far, in spite of the strong interest of researchers in this problem (Riede \& Titze, 2008; Titze \& Riede, 2010; Frey \& Riede, 2013; Volodin et al., 2013). So, a comparison of the acoustics of stag bugles and their imitations by hunters might be interesting, as they potentially can highlight relevant details of the mechanisms of sound production in wapiti.

Siberian wapiti are very elusive and live in habitats difficult to access, however they produce loud, longdistance calls in the rutting period. Therefore, automated recording systems are useful for studying their vocal behaviour in the wild (Blumstein et al., 2011; Mennill et al., 2012). The automated recording systems can be programmed to a fixed time schedule and air temperature can be registered simultaneously. Our purpose was to compare the acoustics of stag rutting bugles, hind alarm calls and bugles imitated by humans and to document relationships between rutting vocal activity of stags and air temperature.

\section{Methods}

Data were collected in period from 16 to $25 \mathrm{Sep}-$ tember, 2012 at the northern foothills of West Sayan Mountains, in the upper parts of Kayzas Valley, near the border of the "Malyi Abakan" territory of the State Natural Reserve "Khakassian", Republic of Khakassia, Russia $\left(52^{\circ} 07^{\prime} 19^{\prime \prime} \mathrm{N}, 89^{\circ} 32^{\prime} 15^{\prime \prime} \mathrm{E}\right)$. This is a narrow valley, with a spring, in the upper part of mountain taiga, extending in meridian direction with a noticeable descent to the north from $1680 \mathrm{~m}$. Forests of Abies sp. and Pinus sp. with large clearings cover the stony slopes of the valley.

We used four automated recording systems Song Meter SM2+ (Wildlife Acoustics Inc., Concord, MA, USA) for acoustic recordings $(22.05 \mathrm{kHz}, 16 \mathrm{bit}$, stereo). Each recording system was equipped with two omni-directional microphones, fixed horizontally under an angle of 180 degrees relative to each other. The recording systems were placed on the valley slopes in a 


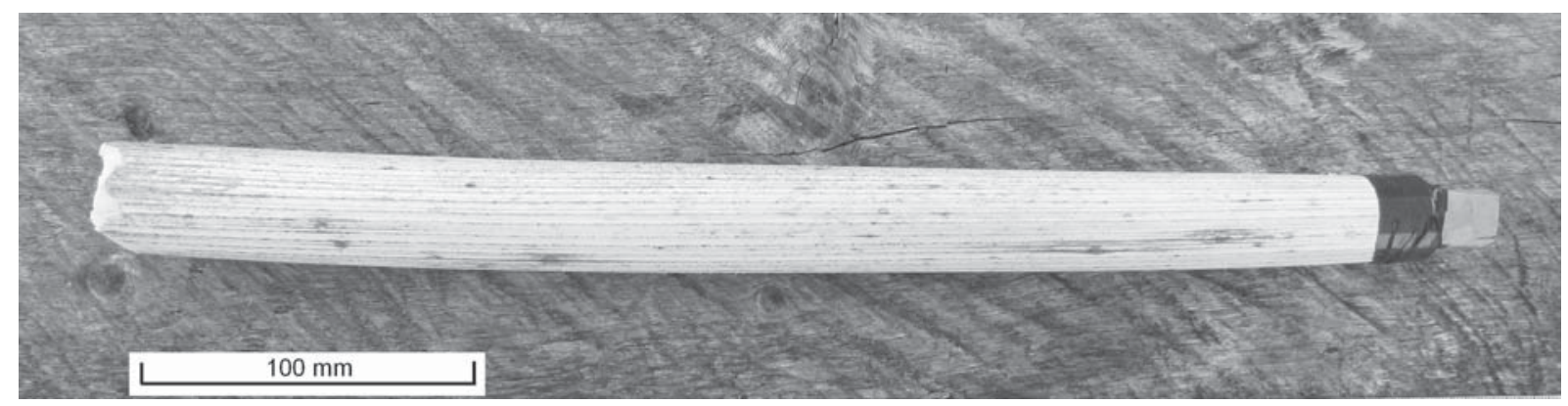

Fig. 1. Traditional instrument of hunters for luring male and female Siberian wapiti. The body of this instrument is made of a hollow stem of a dry plant Heracleum sp. The mouthpiece was obtained by careful trimming of a piece of double-folded birch bark. In the current study, we used this instrument for imitating the rutting bugles of male Siberian wapiti.

broken line. The distances between neighboring recording systems ranged from 500 to $3400 \mathrm{~m}$ between the most distant recording systems. Two of the recording systems were stationary, whereas two others were transferred to various sites during the data collection period.

Sound recording period was set to 15 hours per day, from $17: 00$ to $07: 50$ in a $10 \mathrm{~min}$ recording/10 $\mathrm{min}$ interval schedule, synchronously in all four recording systems. During sound recording, the recording systems registered the air temperature every $5 \mathrm{~min}$. Duration of sound recordings with four automated recording systems was 320 hours in total. During all period of data collection, researchers were in the vicinity of the recording systems (about $700 \mathrm{~m}$ to the nearest). During daylight hours, when the recording systems did not record, researchers walked across the area for revealing places of high rutting activity of Siberian wapiti (feces, tracks, places where stags dig the ground with their antlers, places where stags had rubbed their antlers along young trees).

We confronted sounds recorded synchronously by different recording systems and prepared a sample of 153 rutting bugles in total, where each recorded call was included only once. The number of recorded calls for each hour of recording allowed to calculate the dynamics of male vocal activity on an hourly basis (averages for a given hour, calculated for all 14 days) and on a daily basis (daily averages, calculated for all 15 hours of recording per day). For each hour, we also calculated the average temperature, and by the same way as for the calls, we calculated the dynamics of the average temperature per hour and per day.

To describe the acoustic structure of male rutting bugles we measured the maximum $f 0$ and the duration of each call. The minimum $f 0$ was measured only in calls of good quality, i.e. not strongly degraded by propagation distance and environmental obstacles. For the acoustic measurements, we used Avisoft SASLab Pro software (Avisoft Bioacoustics, Germany, Berlin). Spectrograms were created with a sampling rate of $22.05 \mathrm{kHz}$, Hamming window, Fast Fourier Transform 1024 , frame $50 \%$, and overlap $75 \%$.
We also recorded and analysed alarm calls of one adult female of Siberian wapiti, consisting of a series of 12 barks, produced by the female after having noticed two observers, who had attracted her imitating male rutting bugles. In addition, we analysed 27 imitated bugles produced by a hunter using a hand-made luring instrument. The body of the instrument was constructed by cutting out a hollow piece of stem of a dry plant Heracleum sp. The mouthpiece was obtained by trimming a double-folded small piece of birch bark (Fig. 1). The length of the instrument was $420 \mathrm{~mm}$ without mouthpiece; its internal diameter was $22 \mathrm{~mm}$. For recording the female alarm barks and the imitated male bugles we used a solid state recorder Marantz PMD660 (D\&M Professional, Kanagawa, Japan) with a Sennheiser K6-ME66 microphone (Sennheiser Electronic, Wedemark, Germany). In the female alarm barks and in the imitated male bugles we measured the same acoustic variables and analysed them with the same settings as the natural male rutting bugles.

All statistic analyses were made with STATISTICA, v. 6.0 (StatSoft Inc., Tulsa, OK, USA). All means are given as mean $\pm S D$. For estimating the influence of air temperature on the dynamics of vocal activity we used the Spearman correlation. As some distributions of values departed from normality (Kolmogorov-Smirnov test), we used the non-parametrical Mann-Whitney $U$ test for comparing the acoustic parameter values among stag rutting bugles and bugles imitated by humans.

\section{Results}

Our observations showed that the upper parts of the Kayzas Valley were indeed a rutting place of Siberian wapiti. This was obvious from acoustic recordings by the automated recording systems, the presence of large amounts of old and fresh feces, damaged young trees and from tracks in the freshly fallen snow. In addition, during the data collection we met one adult male and one adult female, who both called in response to imitated male rutting bugles produced by a human. Judging from sequential recordings by the recording systems and from tracks in the snow, the stags regularly moved during the period of data collection. 



Fig. 2. Dynamics of male Siberian wapiti rutting vocal activity and air temperature. Vertical bars represent average numbers of bugles/hour and points connected with line represent average values of air temperature/hour: (A) in each day through the study period from 16 to 29 September 2012; (B) in each hour of day and night from 17:00 to 07:50.

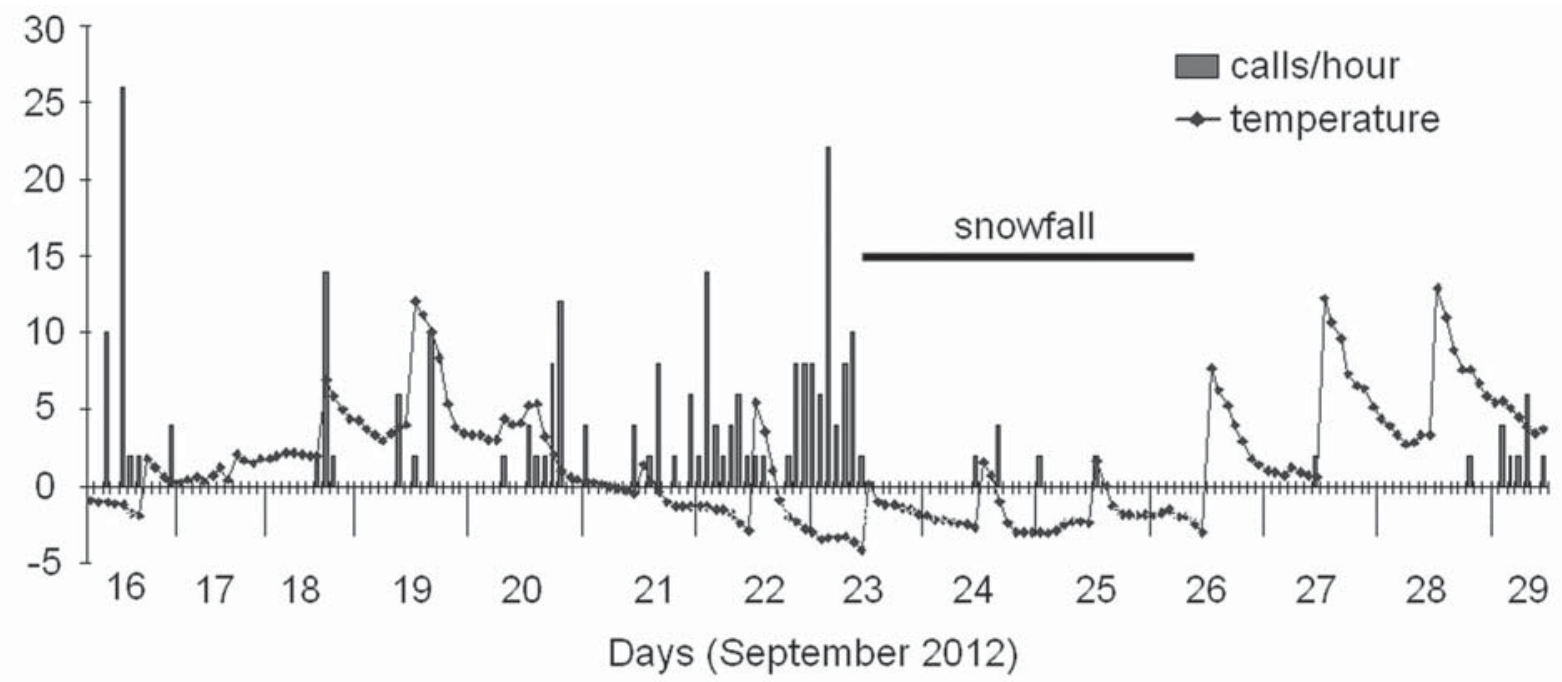

Fig. 3. Dynamics of male Siberian wapiti rutting vocal activity and air temperature, calculated for individual hours over the entire data collection period. Vertical bars represent average numbers of bugles/hour and points connected with line represent average values of air temperature/hour. The black horizontal bar indicates three days of cold and windy weather with strong snowfall.

During our study we did not observe male or female aggregations, so probably animals were dispersed over a large area. Nevertheless, the recorded data documented a few male responses to each other.

The number of male bugles was unevenly distributed among the days of recording (Fig. 2). The maximum number of calls (4.53 per hour) was registered on September 22 , i.e. the day preceding the fall of air temperature that was accompanied by strong snowfall and wind. The number of bugles per hour negatively correlated with air temperature, although the correlation between air temperature and the number of bugles per hour was not significant $\left(r_{s}=-0.42, p=0.13, n=14\right)$.

The number of bugles between the hours of a day was distributed relatively evenly, however during the first half of the night (between 20:00 and 01:00) the stags produced about one third less bugles compared to the second half of the night (between 02:00 and $07: 00)$, i.e. 1.29 and 1.88 bugles per hour respectively (Fig. 2). Within days, the number of bugles per hour also negatively correlated with air temperature, but correlation did not reach significance $\left(r_{s}=-0.39, p=\right.$ $0.15, n=15)$.

However, comparing the number of calls and air temperatures per hour over the entire data collection period, we found a significant negative correlation between the number of calls with the air temperature $\left(r_{s}=\right.$ $-0.15, p<0.05, n=180)$. Vocal activity nearly ceased after September 23 (Fig. 3). This coincided with the decrease of air temperature, wind, snowfall and development of $15 \mathrm{~cm}$ snow cover. Therefore, although the stag vocal activity increased at temperatures slightly 


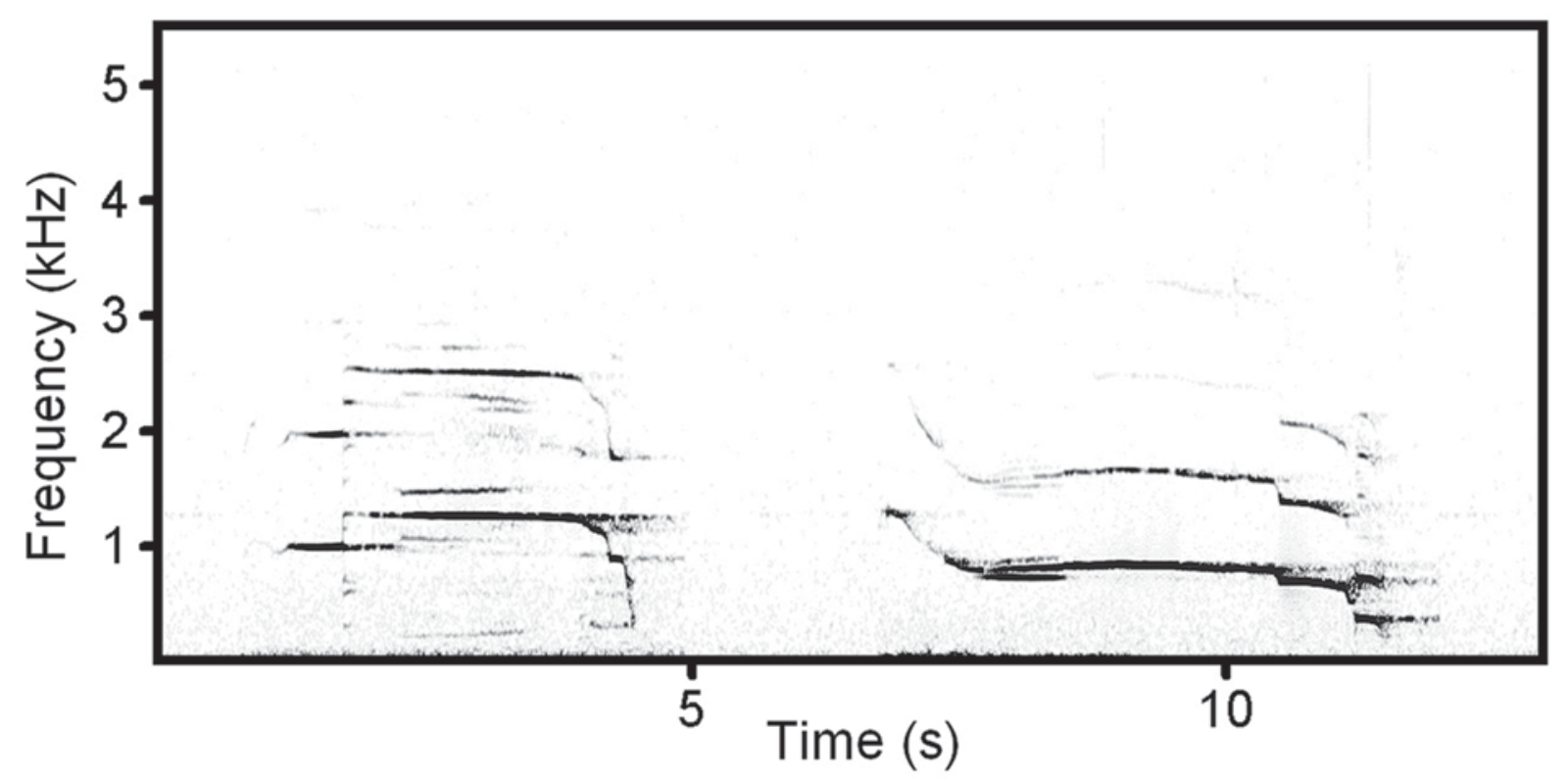

Fig. 4. Spectrogram of two rutting bugles of male Siberian wapiti, recorded by the automated recording systems.

Table 1. Values (mean $\pm S D$; min-max) for acoustic variables of Siberian wapiti stag rutting bugles, bugles imitated by a human, and Mann-Whitney $U$-test results of their comparison. Acoustic variables: maximum $f 0$ - the maximum fundamental frequency; minimum $f O$ - the minimum fundamental frequency; duration - duration of bugles (in seconds).

\begin{tabular}{|l|c|c|l|}
\hline Acoustic variable & Stag bugles & Imitated bugles & Mann-Whitney $U$-test \\
\hline Maximum $f 0(\mathrm{kHz})$ & $1.23 \pm 0.21$ & $1.34 \pm 0.21$ & $U=1470, Z=2.38$, \\
& $0.79-1.89$ & $1.03-1.89$ & $p<0.05$ \\
& $n=153$ & $n=27$ & \\
\hline Minimum $f 0(\mathrm{kHz})$ & $0.29 \pm 0.05$ & $0.87 \pm 0.05$ & $U=0, Z=5.07$, \\
& $0.23-0.40$ & $0.77-0.96$ & $p<0.001$ \\
& $n=13$ & $n=27$ & \\
\hline Duration $(\mathrm{s})$ & $3.07 \pm 0.52$ & $3.19 \pm 0.59$ & $U=647, Z=0.82$, \\
& $2.09-4.63$ & $2.12-4.53$ & $p=0.41$ \\
& $n=54$ & $n=27$ & \\
& &
\end{tabular}

below zero, it nearly stopped during strong snowfall with wind.

Most of the recorded male rutting bugles were substantially degraded because of large distances between the calling animals and the recording systems and because of the landscape complex relief. Most rutting calls were single bugles, and only some of them contained a few short calls subsequent to one longer bugle (Fig. 4). We measured acoustic variables only from the long bugles (Tab. 1). The maximum $f 0$ could be measured in all recorded bugles and was $1.23 \pm 0.21 \mathrm{kHz}$ on average. The minimum $f 0(0.29 \pm 0.05 \mathrm{kHz})$ and the duration $(3.07 \pm 0.52 \mathrm{~s})$ were measured only in bugles of good quality, i.e. not strongly degraded by propagation distance and environmental obstacles (Tab. 1).
The alarm barks of the adult female Siberian wapiti (Fig. 5) had a lower maximum $f 0(0.93 \pm 0.08 \mathrm{kHz}, n=$ $12)$ and a higher minimum $f 0(0.34 \pm 0.06 \mathrm{kHz}, n=10)$ compared to the male rutting bugles. The duration of the female barks was 15 times shorter than the male rutting bugles and lasted only $0.20 \pm 0.03 \mathrm{~s}$.

The imitated bugles were of high-frequency and long duration (Fig. 6). The average maximum $f 0$ of the imitated bugles was $1.34 \pm 0.21 \mathrm{kHz}$, the average minimum $f 0$ was $0.87 \pm 0.05 \mathrm{kHz}$, and the average duration was $3.19 \pm 0.59 \mathrm{~s}$ (Tab. 1). A comparison of natural male rutting bugles with the imitated ones revealed a close similarity in the acoustic structure (Tab. 1). The natural bugles did not differ from the imitated ones by duration; the maximum $f 0$ was slightly but significantly 


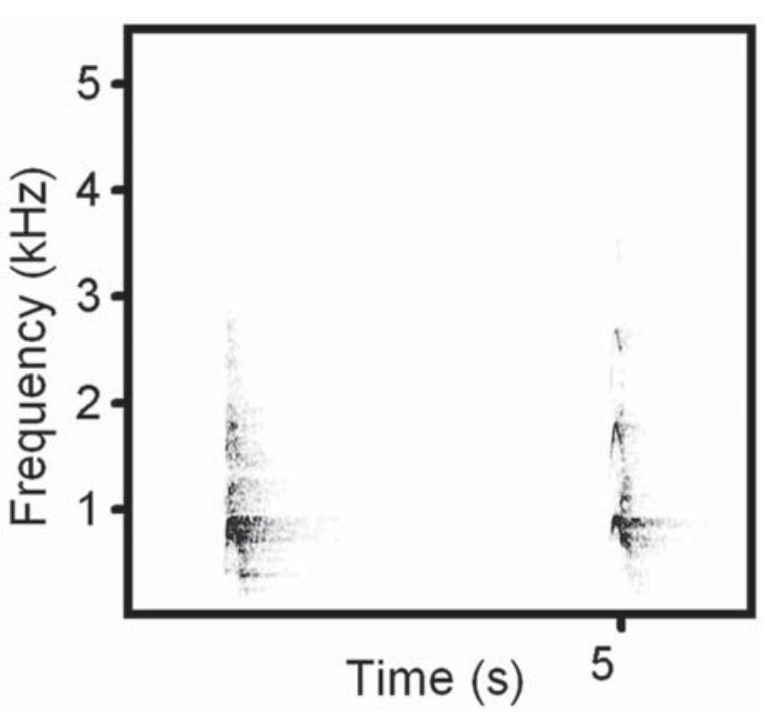

Fig. 5. Spectrogram of two alarm barks of an adult female Siberian wapiti, which had become aware of human observers. wapiti, which also produce mainly single high-pitched long bugles (Nikol'skii et al., 1979; Feighny et al., 2006). The duration of bugles of the Siberian wapiti from Altai is usually more than 2-3 s, and the maximum $f 0$ reaches 1.50 kHz (Nikol'skii et al., 1979; Nikol'skii, 2011). The maximum $f 0$ of Canadian wapiti exceeds 2 $\mathrm{kHz}$, and the duration is 2.4-2.9 s (Struhsaker, 1968; Feighny et al., 2006), whereas the maximum $f 0$ of male Roosevelt wapiti rutting bugles exceeds $1.5 \mathrm{kHz}$ (Bowyer \& Kitchen, 1987).

Compared to Siberian wapiti females, the Canadian wapiti female alarm barks also have a high maximum $f 0$ and a comparable short duration of around $0.25 \mathrm{~s}$ (Struhsaker, 1968). Scottish red deer females produce alarm barks of a similar short duration $(0.22 \mathrm{~s})$, but their maximum $f 0$, however, is much lower $(0.15 \mathrm{kHz})$ (Long et al., 1998). In contrast to our study, alarm barks of female Roosevelt wapiti were registered in the nonrutting period only (Bowyer \& Kitchen, 1987).

The acoustics of rutting bugles of male Siberian wapiti closely resembled the imitated bugles. We observed the similarity in the overall pattern of frequency



Fig. 6. Spectrogram of imitated male bugles of Siberian wapiti. Imitation was performed by an experienced human hunter with the traditional luring instrument depicted in Fig. 1.

higher in the imitated bugles, and only the minimum $f 0$ was almost three times lower in the natural bugles than in the imitated ones. The minimum $f O$ degraded much stronger with distance compared to the maximum $f 0$, so it was missing in about $90 \%$ of the spectrograms of bugles that were recorded at far distance.

\section{Discussion}

The acoustic structure of the rutting bugles of male Siberian wapiti in this study was similar to those of Siberian wapiti from Altai and from North American modulation and in the combination of a high $f 0$ with a prolonged duration (Nikol'skii et al., 1979). In both natural and imitated bugles, the fundamental frequency increased stepwise up to plateau and then decreased stepwise to the end of a call. In some cases the similarity between imitated bugles and natural bugles of male Siberian wapiti extended to fine details of the acoustic structure, such as the appearance of a low-frequency band, visible both in the left natural bugle in Fig. 4 and in the left imitated bugle in Fig. 6. This provides additional support to a hypothesis of forced airflow through a narrow, highly tensed larynx and vocal tract as a 
production mechanism of the extremely high-pitched bugles of wapiti (Frey \& Riede, 2013). This hypothesis assumes incompatibility of this high impedance mechanism with the simultaneous production of a low fundamental frequency, produced by vibration of more relaxed vocal folds. Blowing into the luring pipe through the attached rigid, slit-like mouthpiece produced a low frequency band in the spectrogram. Therefore, the origin of a similar low-frequency band in the natural bugles of Siberian wapiti, too, might not be affected by vibration of the vocal folds. Apart from our study, the low-frequency band in the spectrogram of the bugles of male Siberian wapiti was already described by Nikol'skii (2011). Producing bugles by means of luring pipes of variable lengths and diameters may be considered as a kind of primitive model of vocal production in wapiti. We do not know, however, whether the low-frequency bands are restricted to the bugles of Siberian wapiti or can also be found in other Asian and North American wapiti.

During our study we did neither observe male nor female aggregations, so the males and females were probably dispersed over a large area. Some authors confirm that, during the rut, male Siberian wapiti keep a distance from each other and rarely engage in direct physical conflict (Shtarev, 1970; Fedosenko, 1980), however one stag aggregation was documented (Nikol'skii, 1991). Rutting aggregations of females and males in a restricted area are found in Bactrian, Caucasian (C. e. maral Gray, 1850), Iberian and Canadian subspecies, so that the researcher usually can observe several stags and hinds simultaneously (Struhsaker, 1968; Pereladova, 1981; Frey et al., 2012). Possible explanation for the lack of rutting aggregations in our study site is the short period of data collection, atypical weather, or disturbance of the animals by the presence of humans in the area covered by the automated recording systems.

We could not directly estimate the maximum propagation distance for the rutting bugles of male Siberian wapiti in the mountain taiga forests of our study site. However, comparing the subjective audibility of rutting bugles registered by human listeners with the points of recording of the same bugles by the automated recording systems allowed to estimate the maximum distance of human audibility as $1.5-2 \mathrm{~km}$ in this type of landscape. Similar data were obtained when imitated bugles were recorded at different distances from the automated recording systems. As in the case of the naturally produced rutting bugles, the spectrograms of degraded far-distant imitated bugles contained only parts of $f 0$ maximum plateau.

In summary, this study provides information about acoustic variation of Siberian wapiti vocalization during rut. However, the short samples and the lack of individual recognition suggest for further analyses of vocalization of $C$. e. sibiricus and other Siberian and Far East subspecies of Cervus elaphus.
ACKNOWLEDGEMENTS. We are sincerely thankful to the staff of the Nature State Reserve "Khakassian" for help and support, and especially to Yu.P. Semenov for logistic management, imitating the rutting bugles and assistance in data collection. We are sincerely thankful to A.V. Klenova for providing two automated recording systems. We are sincerely thankful to the two anonymous reviewers, who provided their detailed and valuable comments to the manuscript. This study has been conducted in collaboration with the staff of the Nature State Reserve "Khakassian", in accordance to its Siberian wapiti research project and in accordance to ethical and animal welfare standards. The study has been conducted outside the Reserve territory, in the area of neighboring hunting facilities. Animal disturbance was kept at minimum, and no animal was injured as a result of our work. The study was supported by Russian Foundation for Basic Research (grant \# 12-04-00260a for IV and EV).

\section{References}

Blumstein D.T., Mennill D.J., Clemins P., Girod L., Yao K., Patricelli G., Deppe J.L., Krakauer A.H., Clark C., Cortopassi K.A., Hanser S.F., McCowan B., Ali A.M. \& Kirscehl A.N.G. 2011. Acoustic monitoring in terrestrial environments using microphone arrays: applications, technological considerations, and prospectus // Journal of Applied Ecology. Vol.48. P.758-767.

Bocci A., Telford M. \& Laiolo P. 2013. Determinants of the acoustic behaviour of red deer during breeding in a wild alpine population, and implications for species survey // Ethology, Ecology \& Evolution. Vol.25. P.52-69.

Bowyer R.T. \& Kitchen D.W. 1987. Sex and age-class differences in vocalizations of Roosevelt elk during rut // American Midland Naturalist. Vol.118. P.225-235.

Danilkin A.A. 1999. [Mammals of Russia and Neighboring Regions. Cervidae]. Moskva: GEOS. 552 p. [in Russian].

Fedosenko A.K. 1980. [The Maral (Ecology, Behaviour, Management)]. Alma-Ata: Nauka. 200 p. [in Russian].

Feighny J.J., Williamson K.E. \& Clarke J.A. 2006. North American elk bugle vocalizations: male and female bugle call structure and context // Journal of Mammalogy. Vol.87. P.1072-1077.

Frey R. \& Riede T. 2013. The anatomy of vocal divergence in North American elk and European red deer // Journal of Morphology. Vol.274. P.307-319.

Frey R., Volodin I., Volodina E., Carranza J. \& TorresPorras J. 2012. Vocal anatomy, tongue protrusion behaviour and the acoustics of rutting roars in free-ranging Iberian red deer stags (Cervus elaphus hispanicus) // Journal of Anatomy. Vol.220. P.271-292.

Geist V. 1998. Deer of the world: their evolution, behavior and ecology. Mechanicsburg, Pennsylvania: Stackpole Books. 326 p.

Heptner V.G., Nasimovich A.A. \& Bannikov A.G. 1961. [Mammals of the Soviet Union: Artiodactyla and Perissodactyla]. Vol.1. Moskva: Vishaya Shkola. 776 p. [in Russian]. 
Kidjo N., Cargnelutti B., Charlton B.D., Wilson C. \& Reby D. 2008. Vocal behaviour in the endangered Corsican deer: description and phylogenetic implications // Bioacoustics. Vol.18. P.159-181.

Kuznetsova M.V., Danilkin A.A. \& Kholodova M.V. 2012. [Phylogeography of red deer (Cervus elaphus): data of analysis of polymorphism of the mitochondrial gene for cytochrome $b$ ] // Izvestiya Rossiiskoi Akademii Nauk, Seriya Biologicheskaya. No.4. P.391-398 [in Russian].

Long A.M., Moore N.P. \& Hayden T.J. 1998. Vocalizations in red deer (Cervus elaphus), sika deer (Cervus nippon), and red $\times$ sika hybrids // Journal of Zoology. Vol.224 P.123-134.

Ludt C.J., Schroeder W., Rottmann O. \& Kuehn R. 2004 Mitochondrial DNA phylogeography of red deer (Cervus elaphus) // Molecular Phylogenetics and Evolution. Vol.31. P.1064-1083.

Mahmut H., Masuda R., Onuma M., Takahashi M., Nagata J., Suzuki M. \& Ohtaishi N. 2002. Molecular phylogeography of the red deer (Cervus elaphus) populations in Xinjiang of China: comparison with other Asian, European, and North American populations // Zoological Science. Vol.19. P.485-495.

Mennill D.J., Battiston M., Wilson D.R., Foote J.R. \& Doucet S.M. 2012. Field test of an affordable, portable, wireless microphone array for spatial monitoring of animal ecology and behaviour // Methods in Ecology and Evolution. Vol.3. P.704-712.

Nikolski A.A. \& Wallschlager D. 1983. Interspezifische Divergenz der Brunflaute beim Rothirsch (Cervus elaphus) // Zoologische Jahrbücher, Physiologie. Bd.87. S.353-357.

Nikol'skii A.A. 1975. [Basic patterns of male Bactrian red deer (Cervus elaphus bactrianus) rutting calls] // Zoologicheskii Zhurnal. Vol.54. P.1897-1900 [in Russian].

Nikol'skii A.A. 1984. [Mammalian Acoustical Signals in Evolutionary Process]. Moskva: Nauka. 199 p. [in Russian].

Nikol'skii A.A. 2011. The effect of amplitude modulation on the spectrum structure of the red deer sound signal // Doklady Biological Sciences. Vol.437. P.107-109.

Nikol'skii A.A., Janina I.Yu. \& Frommolt K.-H. 1987. Akustische Diagnostik der Unterartzugehorigkeit der Rothir- sche (Cervus elaphus, Cervidae, Artiodactyla) Transbaikaliens // Zoologischer Anzeiger. Vol.219. P.25-32.

Nikol'skii A.A., Pereladova O.B., Rutovskaja M.V. \& Formozov N.A. 1979. [The geographical variability of rut calls in red deer males] // Byulleten' Moskovskogo Obshchestva Ispytatelei Prirody. Otdel Biologicheskii. Vol.84. No.6. P.46-55 [in Russian].

Passilongo D., Reby D., Carranza J. \& Apollonio M. 2013. Roaring high and low: composition and possible functions of the Iberian stag's vocal repertoire // PLoS ONE. Vol.8(5): e63841. doi:10.1371/journal.pone.0063841.

Pereladova O.B. 1981. [Spatio-temporal dynamics of roaring by Caucasian and Bactrian red deer] // Naumov N.P. (ed.). [Ecology, Population Structure and Intra-Specific Communication Processes in Mammals]. Moskva: Nauka. P.182-244 [in Russian].

Reby D. \& McComb K. 2003. Anatomical constraints generate honesty: acoustic cues to age and weight in the roars of red deer stags // Animal Behaviour. Vol.65. P.519530 .

Riede T. \& Titze I.R. 2008. Vocal fold elasticity of the Rocky Mountain elk (Cervus elaphus nelsoni) - producing high fundamental frequency vocalization with a very long vocal fold // Journal of Experimental Biology. Vol.211. P.2144-2154.

Shtarev J.F. 1970. [Results of acclimatization of maral in the Republic of Mordovia] // Naumov S.P. (ed.). [Proceedings of the Mordovian Natural State Reserve, Issue 5]. Saransk: Mordovian Press. P.137-170 [in Russian].

Struhsaker T.T. 1968. The behavior of the elk (Cervus canadensis) during the rut // Zeitschrift für Tierpsychologie. Vol.24. S.80-114.

Tembrock G. 1965. Untersuchungen zur intraspezifischen Variabilität von Lautäußerungen bei Säugetieren // Zeitschrift für Säugetierkunde. Bd.30. S.257-273.

Titze I.R. \& Riede T. 2010. A cervid vocal fold model suggests greater glottal efficiency in calling at high frequencies // PLoS Computational Biology. Vol.6(8): e1000897. doi:10.1371/journal.pcbi.1000897.

Volodin I., Volodina E., Frey R., Carranza J. \& TorresPorras J. 2013. Spectrographic analysis points to sourcefilter coupling in rutting roars of Iberian red deer // Acta Ethologica. Vol.16. P.57-63. 